\title{
Spatial distribution of bivalvia (Mollusca) in the soft-bottoms of Ilha Grande Bay, Rio de Janeiro, Brazil
}

\author{
Maria Cláudia Guimarães Grillo ${ }^{1}$, Carlos Renato R. Ventura ${ }^{2} \&$ Sérgio Henrique Gonçalves da Silva ${ }^{1}$
}

Instituto de Biologia da Universidade Federal do Rio de Janeiro

${ }^{1}$ Departamento de Biologia Marinha

${ }^{2}$ Departamento de Invertebrados, Museu Nacional

(CCS- Bloco A. Cidade Universitária 21949-900, Rio de Janeiro, RJ, Brazil)

- Abstract: The spatial distribution of bivalve molluscs and its relation to granulometry and to the percentage of organic matter and silt-clay were studied in the Saco do Céu Inlet. Bivalves and samples of sediment were collected in 39 stations, in January and July 1992, using a $0.1 \mathrm{~m}^{2}$ Petersen grab. The type of sediment varied from very fine to coarse sand. Nineteen species of bivalves were quantified, 14 of which were present in the two periods of the year. The highest diversity was found in medium and fine sand in summer and in coarse sand in winter. These bottoms presented a greater structural heterogeneity. A community dominated by Corbula caribaea was distinguished in fine bottoms with relative high content of organic matter, whereas another community dominated by Anomalocardia brasiliana occurred in coarser bottoms. Both communities were distributed in continuum along a sediment gradient.

- Resumo: A distribuição espacial dos bivalves e sua relação com a granulometria e os teores de matéria orgânica e silte-argila foram estudados no Saco do Céu. Obteve-se amostras de fauna e sedimento em 39 estações nos meses de janeiro e julho de 1992, utilizando-se um busca-fundo de Petersen de $0,1 \mathrm{~m}^{2}$. O sedimento variou de areia fina a areia grossa. Foram quantificadas 19 espécies sendo que 14 ocorreram nos dois períodos do ano. Os fundos de areia média e fina no verão e areia grossa no inverno apresentaram os maiores valores de diversidade e uma maior heterogeneidade estrutural. Evidenciou-se a existência de uma comunidade dominada por Anomalocardia brasiliana em fundos grossos e outra dominada por Corbula caribaea em fundos finos, ricos em matéria orgânica. Ambas distribuíram-se em contínuo, ao longo de um gradiente sedimentológico.

- Descriptors: Spatial distribution, community structure, bivalvia, soft-bottom, shallow-water, Itha Grande Bay, southeastern Brazil.

- Descritores: Distribuição espacial, estrutura de comunidades, bivalvia, fundos rasos, Baía de Ilha Grande, Brasil. 


\section{Introduction}

The description of spatial patterns in the distribution and abundance of species is an essential step towards assessing the ecological processes which structure communities (Jones et al., 1990; James et al., 1995). Among abiotic factors that control coastal soft-bottom marine communities, the importance of sediment grain size is emphasized (Gray, 1981; Morrisey et al., 1992; Diener et al., 1995). Grain size directly affects biologically relevant variables such as porosity, oxygen tension, pore water content, retention or absorption of particulate carbon and contaminants and redox depth (Diener et al., op. cit.).

Molluscs are distinguished in tropical shallow water benthic communities, both in terms of abundance and species richness (Gonçalves \& Lana, 1991). Investigations into the ecological role played by molluscs must be founded upon fundamental information on the species present, their distribution and abundance and the relationship between abundance and features of the habitat (Jones et al., op. cit.).

The presence of the major oil terminal of Latin America at Ilha Grande Bay (Petrobrás, 1991) represents a potential source of disturbance to affect the marine community. In this sense, knowledge of the natural spatial and temporal distribution of benthic organisms, which are often used as indicators of pollution (Dauer, 1993; Soetaert et al., 1994), is essential when assessing and comparing the effects of any disturbance (Anderlini \& Wear, 1992; Bachelet et al.,1996). Few studies (Neme, 1979; Sanches, $1989^{*}$ ) have examined the ecology of soft-bottom marine communities at the study area. Comparisons between these studies and the present study are difficult due to either the methodology utilized (Neme, op. cit.) or the zoological group studied (Sanches, op. cit.).

The purpose of this study was to determine the spatial distribution of Bivalvia (Mollusca) from a shallow water bay in Angra dos Reis, Rio de Janeiro.

\section{Materials and methods}

\section{Study site}

Ilha Grande Bay is located at the southeastern coast of Rio de Janeiro State $\left(44^{\circ} 45^{\prime}\right.$ to $44^{\circ} 00^{\prime} \mathrm{W}$,

(*) Sanches, T. M.; Eichler, B. B. \& Mahiques, M. M. de 1989. Distribuição dos foraminiferos recentes na Baía da Ilha Grande, Estado do Rio de Janeiro. In: SIMPÓSIO SOBRE OCEANOGRAFIA, 1. Resumos. São Paulo, IOUSP. p.194.
$22^{0} 50^{\prime}$ to $23^{\circ} 20^{\prime} \mathrm{S}$ ). The climate is tropical with dry winters and rainy summers. Mean precipitation in the summer $(270 \mathrm{~mm})$ was almost four times higher than in the winter $(70 \mathrm{~mm})$ for last 20 years (1974 to 1994).

The Saco do Céu Inlet, located on the east coast of Ilha Grande Bay (Fig. 1), is a low-energy unpolluted shallow water inlet between 2 and 9 meters deep ( $c a 1 \mathrm{~km}^{2}$ in area) with sandy bottoms (IEF, 1992).

\section{Sampling and laboratory analysis}

In January (summer) and July (winter) 1992, sediment samples were collected from 39 stations in the Saco do Céu Inlet. The sampling procedure consisted of three samples taken at each station, using a $0.1 \mathrm{~m}^{2}$ Petersen grab, for biological analysis and an additional sample for sediment analysis. Faunal samples were sieved through $0.5 \mathrm{~mm}$ meshes and fixed in $5 \%$ formaldehyde. Bivalves were identified to species level and quantified as mean numbers per station. Sediment samples were subjected to grain size analyses according to Ingram (1971) and the organic matter content was estimated as the loss in weight of dried sediment $\left(100^{\circ} \mathrm{C}, 24 \mathrm{~h}\right)$ after combustion $\left(500^{\circ} \mathrm{C}, 3 \mathrm{~h}\right)$ (Suguio, 1973).

\section{Data analysis}

Mean particle size and the degree of sorting were determined following Folk \& Ward (1957). Relationships between the percentage of organic matter and the water column depth (corrected for tides) and between the percentage of silt-clay and water column depth were obtained using Spearman rank correlation (Siegel, 1975). Sampling stations from summer and winter were assembled in groups according to their mean grain size. For each group, the percentage abundance (a) and frequency (f) of each species were calculated and are defined as:

$\mathrm{a}=\mathrm{Na} /(\mathrm{Na}+\mathrm{Nb}+. .+\mathrm{Nn}) \cdot 100 ;$

where $\mathrm{Na}, \mathrm{Nb} . \mathrm{Nn}$ are the numbers of individuals of species "a", "b", .. " $n$ " and

$\mathrm{f}=\mathrm{Pa} / \mathrm{P} \cdot 100$; where $\mathrm{Pa}$ is the number of stations in which species "a" occur and $P$ is the total number of stations in the group. 
Characteristic species (those of $>50 \%$ abundance) were also determined in each type of sediment, following Palacin et al. (1991). Shannon Diversity index $\left(\log _{\mathrm{e}}\right)$ and Evenness (Pielou, 1969) were calculated for seven stations of each group (coarse, medium, fine and very fine sand) in the summer and of the two most representative groups (coarse and fine) in the winter. The number of stations needed to represent species richness in each type of sediment was obtained from a species-area curve. Relationships among sampling stations were determined by Morisita Modified Similarity Index (Horn, 1966) and then subjected to both clustering and ordination analysis. Clustering was by Agglomerative Hierarchical Cluster Analysis (Ludwig \& Reynolds, 1988) and ordination was by Principal Component Analysis.

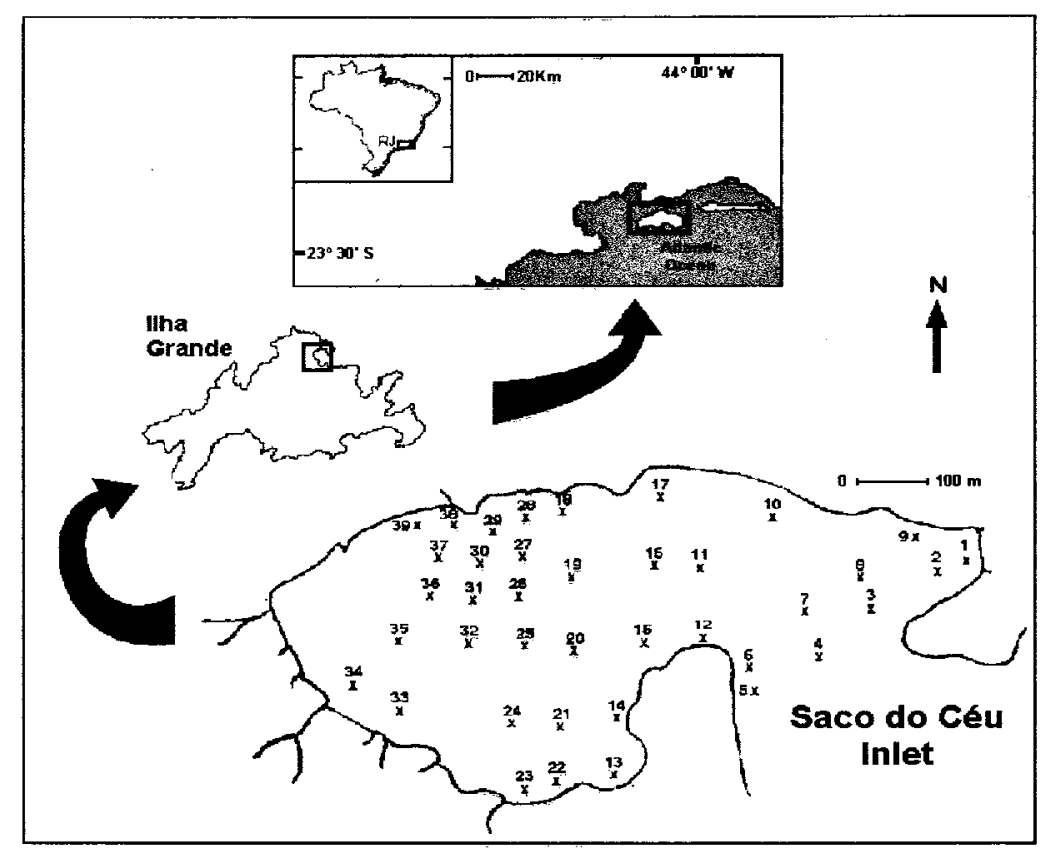

Fig. 1. Map of the study area showing station locations.

\section{Results}

All samples collected in the summer consisted of sandy sediments. About $32 \%$ of the stations were characterized by fine sand (mean $=0.17$ $\mathrm{mm}), 26 \%$ of the stations were characterized by coarse sand (mean $=0.64 \mathrm{~mm}$ ), $21 \%$ by medium sand (mean $=0.31 \mathrm{~mm}$ ) and $21 \%$ by very fine sand (mean $=0.07 \mathrm{~mm}$ ). Five types of sandy sediments were evident in the winter: coarse sand $(42 \%$ of stations) (mean $=0.64 \mathrm{~mm})$, fine sand $(39 \%$ of stations) (mean $=0.20 \mathrm{~mm}$ ), medium sand $(10 \%)$ (mean $=0.28 \mathrm{~mm})$, very coarse sand $(6.5 \%)$ $(m e a n=1.08)$ and very fine sand $(3.0 \%)$ (mean $=0.01$ $\mathrm{mm}$ ) (Fig. 2). Sediments were markedly poorlysorted in both periods.

The highest values of organic matter and siltclay were found in fine and very fine sandy stations
(Table 1). The percentage of organic matter and siltclay were directly correlated with depth in both seasons (Table 2).

\section{Abundance and frequency of species}

In the summer, a total of 1,673 organisms from 19 species of bivalves were quantified (Table 3). Anomalocardia brasiliana was the dominant species in both coarse and medium sand and classified as the characteristic species of coarse sand. In fine sand, Codakia costata and $A$. brasiliana were dominant. Corbula caribaea was the dominant species in very fine sand and the most frequent species in both coarse and fine bottoms. 
In the winter, a total of 553 individuals from 15 species of bivalves were found (Table 3). Codakia orbiculata and $A$. brasiliana were the dominant species in coarse sand. Corbula caribaea was the most abundant species in medium, fine and very fine sand, a characteristic species in the finest sediments and the most frequent species in all types of sediment except in very fine sand.

\section{Specific Diversity}

In the summer, the highest values of diversity and evenness were recorded in medium and fine sand, whereas the lowest were measured in coarse and very fine sand. In the winter, the highest values of diversity and evenness were found for coarse sand (Table 4).

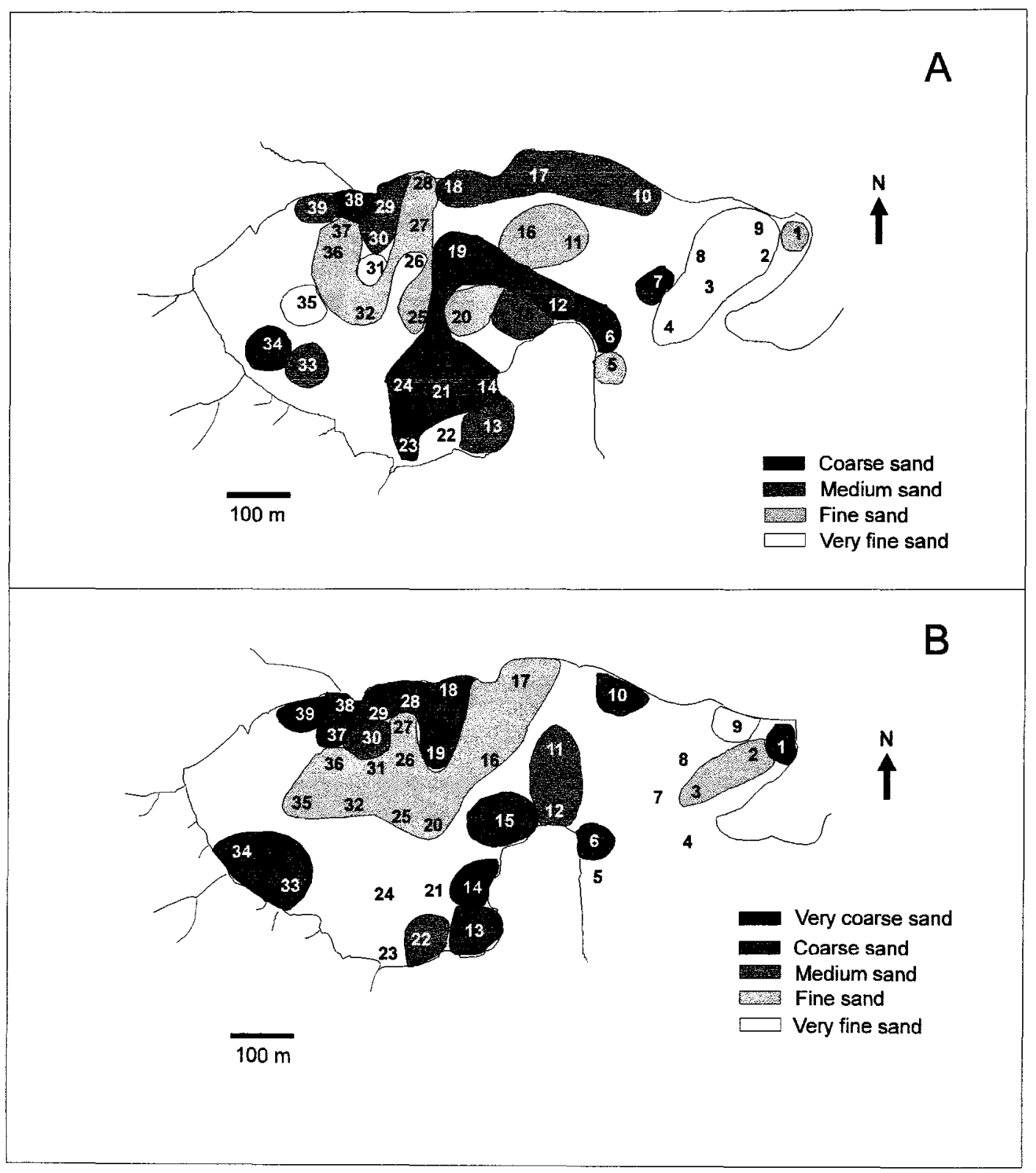

Fig. 2. Spatial distribution of the different types of sediment sampled in Saco do Céu Inlet in (A) summer and (B) winter. 
Table 1. Mean values of organic matter (O.M.) and silt-clay (S.C.) at the different types of sediment in Saco do Céu Inlet, in summer and winter. ( VCS= very coarse sand; $C S=$ coarse sand; $M S=$ medium sand; $F S=$ fine sand; VFS $=$ very fine sand). Numbers in parenthesis are standard deviations.

\begin{tabular}{|c|c|c|c|c|c|c|c|c|c|}
\hline & & & & $\begin{array}{l}\text { Types of } \\
\text { sediment }\end{array}$ & & & & & \\
\hline & & & Summer & & & & Winter & & \\
\hline & $\mathrm{CS}$ & MS & FS & VFS & VCS & CS & MS & FS & VFS \\
\hline$\%$ O.M. & $3.6(4.5)$ & $9.9(12.7)$ & $15.8(5.8)$ & $18.8(1.5)$ & $1.4(0.1)$ & $7.9(3.2)$ & $19.3(6.2)$ & $20.2(1.5)$ & --- \\
\hline$\%$ S.C. & $1.2(1.8)$ & $3.0(3.0)$ & $7.9(5.3)$ & $19.2(6.1)$ & $0.5(0.6)$ & $2.3(2.8)$ & $7.4(4.3)$ & $10.4(8.5)$ & 38.6 \\
\hline
\end{tabular}

Table 2. Spearman rank correlations between the percentages of organic matter (O.M.) and water column depth and between the percentage of silt-clay (S.C.) and water column depth.

\begin{tabular}{lcc}
\hline & SUMMER & WINTER \\
\hline O.M.x Depth & rs $=0.71$ & rs $=0.53(p=0.0145)$ \\
S.C. $x$ Depth & rs $=0.67$ & $r s=0.71(p=0.0001)$ \\
\hline
\end{tabular}

\section{Cluster Analysis}

Hierarchical Cluster Analysis confirmed the relationships observed among species distribution and grain size in both seasons. Six major groups were evident in the summer (similarity level of 0.5 ) (Fig. 3). Corbula caribaea was the dominant and most frequent species in station group $\mathrm{A}$, which was mainly characterized by very fine $(39 \%$ of the stations) and fine sand (33.3\%). On the other hand, $A$. brasiliana was the dominant and most frequent species in station group $\mathrm{F}$, characterized by coarse sand $(50 \%$ of the stations) and medium sand $(33.3 \%)$. Five major groups were revealed in the winter (similarity level of 0.5) (Fig. 4). Corbula caribaea was the dominant and most frequent species in station groups mainly characterized by fine sands (group A- $60 \%$ of the stations), whereas $A$. brasiliana was the most represented species in coarse sand (group E-50\%).

\section{Ordination}

The first two axes of variability accounted for $56.8 \%$ of the total variance. Spearman Rank Correlation indicated that the first axis of variability was strongly correlated with depth and percentage of organic matter (Table 5). Station group I (Fig. 5a) presented both the highest mean depth values $(6.6 \mathrm{~m}$ $\pm 2.0)$ and percentage of organic matter $(19.2 \% \pm$ 3.0 ), being characterized by the dominance of $C$. caribaea (Fig. $5 \mathrm{~b}$ ). The second axis of variability was not significantly correlated with depth and percentage of organic matter (Table 5). Nevertheless, station group II (Fig. 5a) presented the lowest mean depth values $(0.4 \mathrm{~m} \pm 0.6)$ and the lowest percentage of organic matter $(1.4 \% \pm 0.6)$, being characterized by the dominance of $A$. brasiliana (Fig. 5b). The other stations were characterized by mean depth values of $3.3 \mathrm{~m} \pm 2.0$ and organic matter values of $8.4 \% \pm 6.3$. These stations consisted of different dominant species which were concentrated around the origin of the axes (Fig. 5b).

\section{Discussion}

The Saco do Céu Inlet was markedly characterized by poorly diversified sandy bottoms in both seasons. Sediment heterogeneity was a reflection of the low tidal energy observed in the inlet. Gray (1981) stated that particle deposition depends on many factors, including current speed, the roughness of the sediment and the period of hydrodynamic stability. Well-sorted sediments are typical of high-energy areas whereas those more heterogeneous are observed in low-energy areas. 


\section{Bivalve Community Structure}

\section{Spatial distribution of dominant species}

Anomalocardia brasiliana occurred in sediments with low amounts of silt-clay. Abundance of $A$. brasiliana decreased from a total of 845 individuals collected in the summer to 63 in the winter. Such a reduction might be influenced by the increase in the mean percentage of silt-clay and organic matter recorded in the winter, mainly in medium and fine sand where $A$. brasiliana decreased to zero. Suspension-feeders, such as $A$. brasiliana, mostly occur in sandy bottoms which are relatively free from large amounts of silt-clay (Sanders, 1958; Nybakken, 1988) and rely on food supplied by the water column (Kamermans et al., 1992). Sediments markedly characterized by coarse particles are typical of relatively high current activities areas which, in consequence, exhibit a better availability of feeding particles in the water column than fine sediments (Levinton, 1972). Coarse fractions are less often subjected to resuspension, mainly by the activities of burrowing organisms. Resuspended sediment may cause the clogging of filtering structures, rendering them unusable (Rhoads \& Young, 1970). Schaeffer-Novelli (1980) and Lana et al. (1989) showed that $A$. brasiliana occurred in areas characterized by sandy sediments and low percentages of organic matter at the southeastern littoral of Brazil.

Corbula caribaea is more frequent in muddy bottoms at the Brazilian southeastern mid-shelf, between 50 and 120 meters deep and in sandy and muddy bottoms in low-energy bays and inlets (Gonçalves \& Lana, 1991). According to Domschke (1978), few particles suspended in the water column may be the main source of food for C. caribaea due to its inhalant siphon structure. Nevertheless, as the inhalant siphon remains at the surface of the sediment, $C$. caribaea can actively vacuum clean the sediment surface and particles deposited around the siphonal aperture could be carried into the mantle cavity (Domschke, op. cit.). Furthermore, morphological evidence, such as separate siphons, indicate that $C$. caribaea is a deposit feeder. In fact, C. caribaea was dominant in bottoms with the highest values of organic matter and silt-clay.

Corbula caribaea was absent from the stations where $A$. brasiliana occurred, in coarse, medium and fine sediments both in summer and winter. Anomalocardia brasiliana was the dominant species in the Saco do Céu Inlet and exhibited a highly aggregate distribution pattern $\left(\sigma^{2} / \mu>50\right.$ in the summer and $\sigma^{2} / \mu>5$ in the winter). This fact suggests that this bivalve strongly utilizes the spatial resource, which in turn may become less available to
C. caribaea. Moreover, dense aggregates of a suspension feeder (like $A$. brasiliana) may also exclude any potential deposit feeders, such as $C$. caribaea by filtering larvae out of the water column (Nybakken, 1988).

\section{Specific diversity}

Bivalve diversity varied both among the different types of sediment and seasons of the year. In the winter, the dominance decrease of $A$. brasiliana resulted in higher values of diversity in coarse sand whereas the dominance of $C$. caribaea determined the low diversity measured in the finest sediments.

Specific diversity appears to be correlated with sediment structure (Fresi et al., 1983). Fine sediments mainly characterized. by silt-clay are structurally homogeneous. On the other hand, poorly-sorted sediments can be expected to give more structural heterogeneity and potential niche space and therefore higher diversity (Gray, 1981). Although the Saco do Céu Inlet was markedly characterized by poorly-sorted sediments, the occurence of a higher percentage of silt-clay at some stations could determine a reduced niche space, as described by Gray (op. cit.), compared to coarser bottoms. This pattern may have lead to the lowest species diversity and the higher dominance of C.caribaea in those finest bottoms.

\section{Spatial distribution of bivalve communities}

According to Mills (1969), natural populations overlap in distribution along gradients of environmental factors; i.e. one community grades into another. Two distinctly structured communities were evident in this study with regard to dominance of species, being subjected to different environmental conditions. One of these communities occurred in the finest bottoms which characterized station group A and was dominated by $C$. caribaea. The other community occurred at the coarser bottoms, corresponding to the species found in station group $\mathrm{E}$ (winter) and $\mathrm{F}$ (summer). This community was dominated by $A$. brasiliana. Between these extremes, there was an intermediate group of stations characterized by species which were poorly represented in the communities outlined above. Such species were distributed in the form of continua, reflecting the existence of gradients of environmental factors, markedly sediment gradients. Franz (1976) reported a gradation of bivalve species composition from one community into another as a response to sediment gradients. Bachelet et al. (1996) also described two well-defined macrobenthic communities and an intermediate one comprising species found in the former communities. 
Table 3. Abundance $(\%)$ and Frequency $(\%)$ of Bivalvia species. $(\mathrm{CS}=$ coarse sand; MS $=$ medium sand; $\mathrm{rS}=$ =fine sand; VFS $=$ very fine sand). $A=$ abundance; $F=$ frequency. No specimens were collected in very coarse sand stations.

\begin{tabular}{|c|c|c|c|c|c|c|c|c|c|c|c|c|c|c|c|c|}
\hline & \multicolumn{16}{|c|}{ Types of sediment } \\
\hline & \multicolumn{8}{|c|}{ Summer } & \multicolumn{8}{|c|}{ Winter } \\
\hline & \multicolumn{2}{|c|}{$\mathrm{CS}$} & \multicolumn{2}{|c|}{ MS } & \multicolumn{2}{|r|}{ FS } & \multicolumn{2}{|c|}{ VFS } & \multicolumn{2}{|c|}{ CS } & \multicolumn{2}{|c|}{ MS } & \multicolumn{2}{|c|}{ FS } & \multicolumn{2}{|c|}{ VFS } \\
\hline & $\mathbf{A}$ & $\mathbf{F}$ & $\mathbf{A}$ & $\mathbf{F}$ & $\mathbf{A}$ & $\mathbf{F}$ & $\mathbf{A}$ & $\mathbf{F}$ & $\mathbf{A}$ & $\mathbf{F}$ & $\bar{A}$ & $\mathbf{F}$ & $\mathbf{A}$ & $\mathbf{F}$ & A & $\mathbf{F}$ \\
\hline Anomalocardia brasiliana & 74 & 44 & 40 & 43 & 23 & 18 & - & - & 16 & 23 & - & - & - & - & - & - \\
\hline Cardiomya cleryana & 0.1 & 11 & - & - & - & - & - & - & - & - & - & - & - & - & - & $\cdot$ \\
\hline Chione paphia & 1.0 & 33 & 0.4 & 29 & 0.4 & 9.1 & - & - & 4.9 & 23 & - & - & - & - & - & - \\
\hline Codakia costata & 1.3 & 56 & 6.1 & 57 & 26 & 18 & - & - & 15 & 7.7 & - & - & - & - & - & - \\
\hline Codakia orbiculata & 1.1 & 44 & 2.7 & 71 & 1.8 & 18 & - & - & 17 & 31 & 13 & 33 & - & - & 11 & 100 \\
\hline Codakia pectinella & - & - & 0.8 & 14 & 5.9 & 9.0 & - & . & - & - & - & - & - & - & - & - \\
\hline Corbula caribaea & 3.9 & 78 & 9.2 & 57 & 16 & 82 & 72 & 100 & 13 & 46 & 45 & 67 & 75 & 83 & 67 & 100 \\
\hline Crassinella lunulata & 2.3 & 22 & 1.0 & 29 & - & - & - & - & 1.1 & 15 & - & - & - & - & - & - \\
\hline Diplodonta punctata & - & - & - & - & - & - & - & - & 7.5 & 39 & - & - & - & - & - & - \\
\hline Ervilia concentrica & 1.0 & 11 & 3.3 & 29 & - & - & - & - & 1.9 & 15 & - & - & - & - & - & - \\
\hline Felaniella viladerboana & - & - & 1.2 & 57 & 9.5 & 73 & 9.9 & 100 & 1,5 & 7.7 & 16 & 33 & 20 & 83 & 22 & 100 \\
\hline Gouldia cerina & 5.8 & 56 & 4.3 & 43 & 0.4 & 9.1 & - & - & 7.8 & 31 & - & - & - & - & - & - \\
\hline Laevicardium laevigatum & - & - & - & - & - & - & - & $=$ & $=$ & . & - & - & - & - & - & - \\
\hline Lioberus castaneus & - & - & - & - & - & - & - & + & - & $=$ & - & - & - & - & - & - \\
\hline Lucina pectinata & 1.0 & 22 & 0.4 & 14 & 0.4 & 9.0 & - & - & - & . & - & - & - & - & - & - \\
\hline Macoma tenta & 0.1 & 11 & 0.4 & 14 & 1.5 & 36 & 17 & 86 & $=$ & - & 13 & 33 & 0.5 & 25 & - & - \\
\hline Nucula semiornata & 0.8 & 33 & 3.5 & 29 & 5.5 & 27 & - & - & 11 & 39 & - & - & - & - & - & - \\
\hline Solemya patagonica & - & - & 1.6 & 14 & - & - & - & - & - & - & - & - & - & - & - & - \\
\hline Tellina gibber & 2.2 & 56 & 2.2 & 29 & 3.7 & 27 & 0.9 & 14 & 0.4 & 7.7 & - & - & - & - & - & - \\
\hline Tellina lineata & 4.8 & 33 & 21 & 29 & 2.9 & 18 & - & - & 1.1 & 31 & 13 & 33 & 3.9 & 8.3 & - & - \\
\hline Trachycardium muricatum & 0.1 & 11 & 1.4 & 43 & 2.9 & 9.0 & - & - & 1.9 & 15 & - & - & - & - & - & - \\
\hline Transenella stimpsoni & 0.1 & 11 & 0.8 & 14 & 0.4 & 9.1 & - & - & - & - & - & - & - & - & - & - \\
\hline
\end{tabular}


Table 4. Shannon species diversity $(\log \mathrm{e})$ and evenness (in parenthesis) at the most representative types of sediment in summer and winter. $\mathrm{CS}=$ coarse sand; $\mathrm{MS}=$ =medium sand; $\mathrm{FS}=$ fine sand;VFS=very fine sand.

\begin{tabular}{lcccc}
\hline & CS & MS & FS & VFS \\
\hline SUMMER & $1.09(0.40)$ & $1.99(0.69)$ & $2.02(0.84)$ & $0.81(0.58)$ \\
WINTER & $2.27(0.86)$ & - & $0.67(0.48)$ & $\ldots$ \\
\hline
\end{tabular}

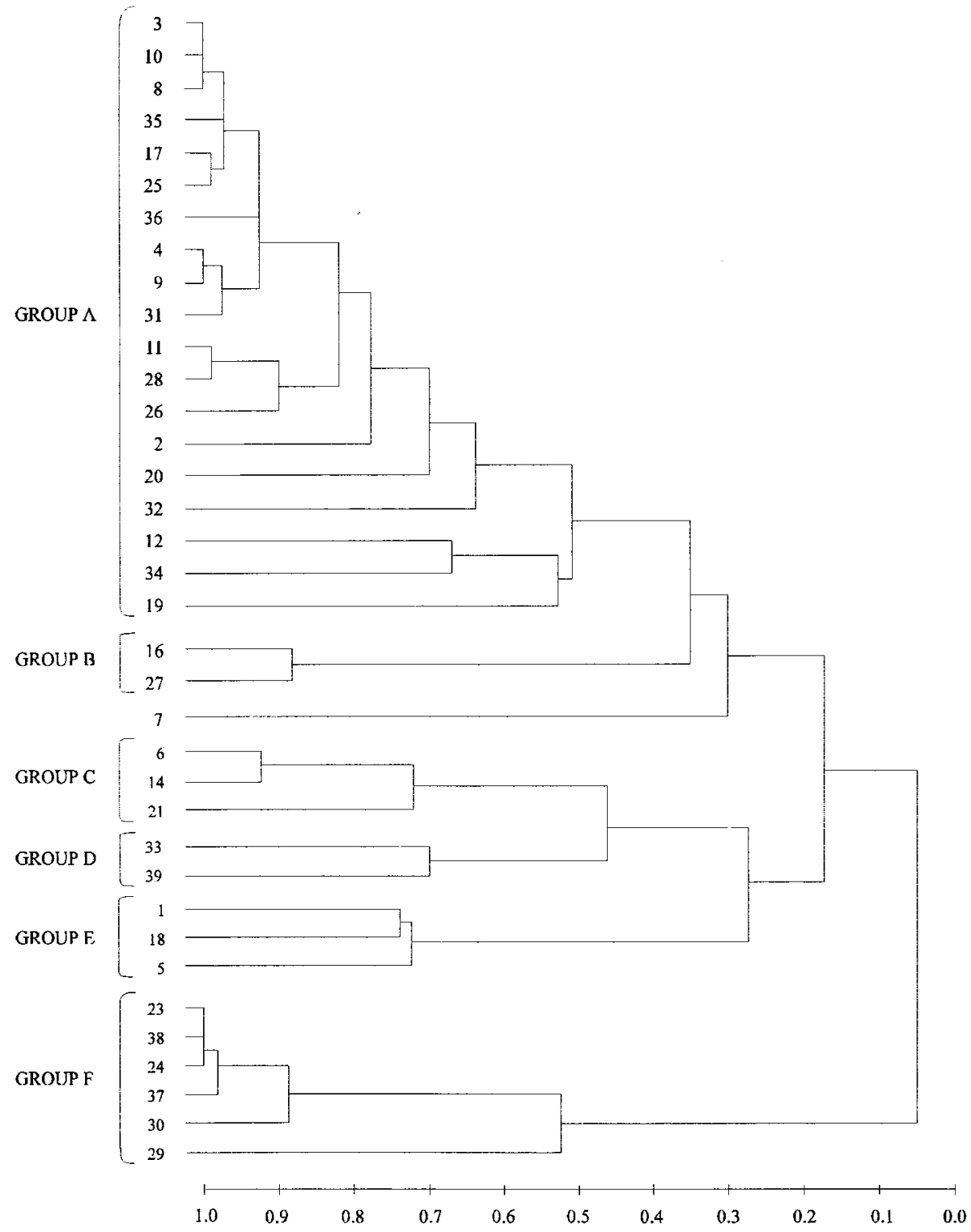

Fig. 3. Dendrogram showing the major groups obtained from hierarchical classification among stations in relation to abundance of species in summer. 


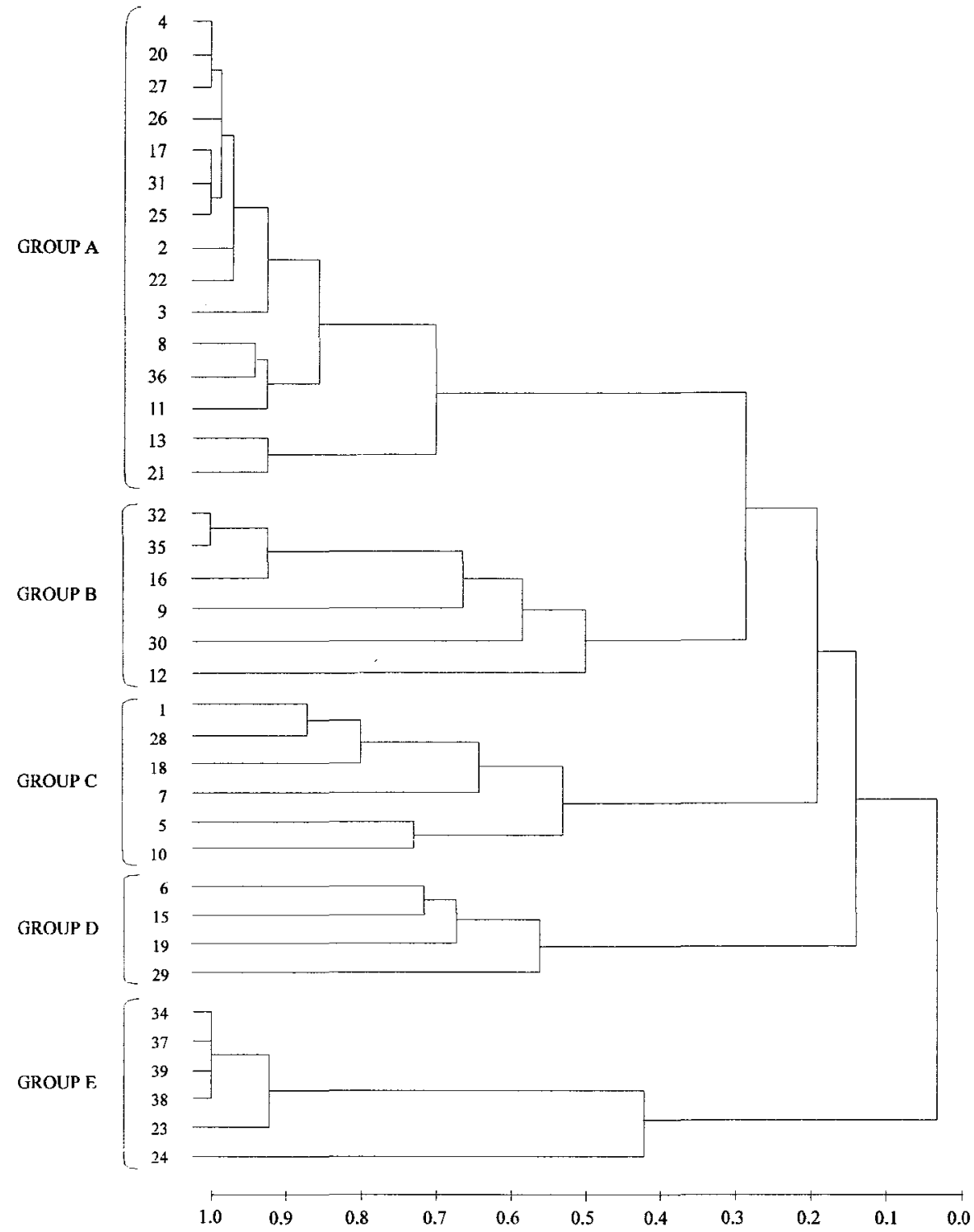

Fig. 4. Dendrogram showing the major groups obtained from hierarchical classification among stations in relation to abundance of species in winter.

Table 5 -Spearman rank correlations between the coordinates from principal components axes (I and II) and abiotic factors. ${ }^{*} \mathrm{P}<0.05$

\begin{tabular}{lcc}
\hline & AXIS 1 & AXIS 2 \\
\hline Depth & $0.6882^{*}$ & 0.1766 \\
\% silt-clay & $0.4196^{*}$ & 0.2692 \\
\% organic matter & $0.6497^{*}$ & 0.1813 \\
\hline
\end{tabular}



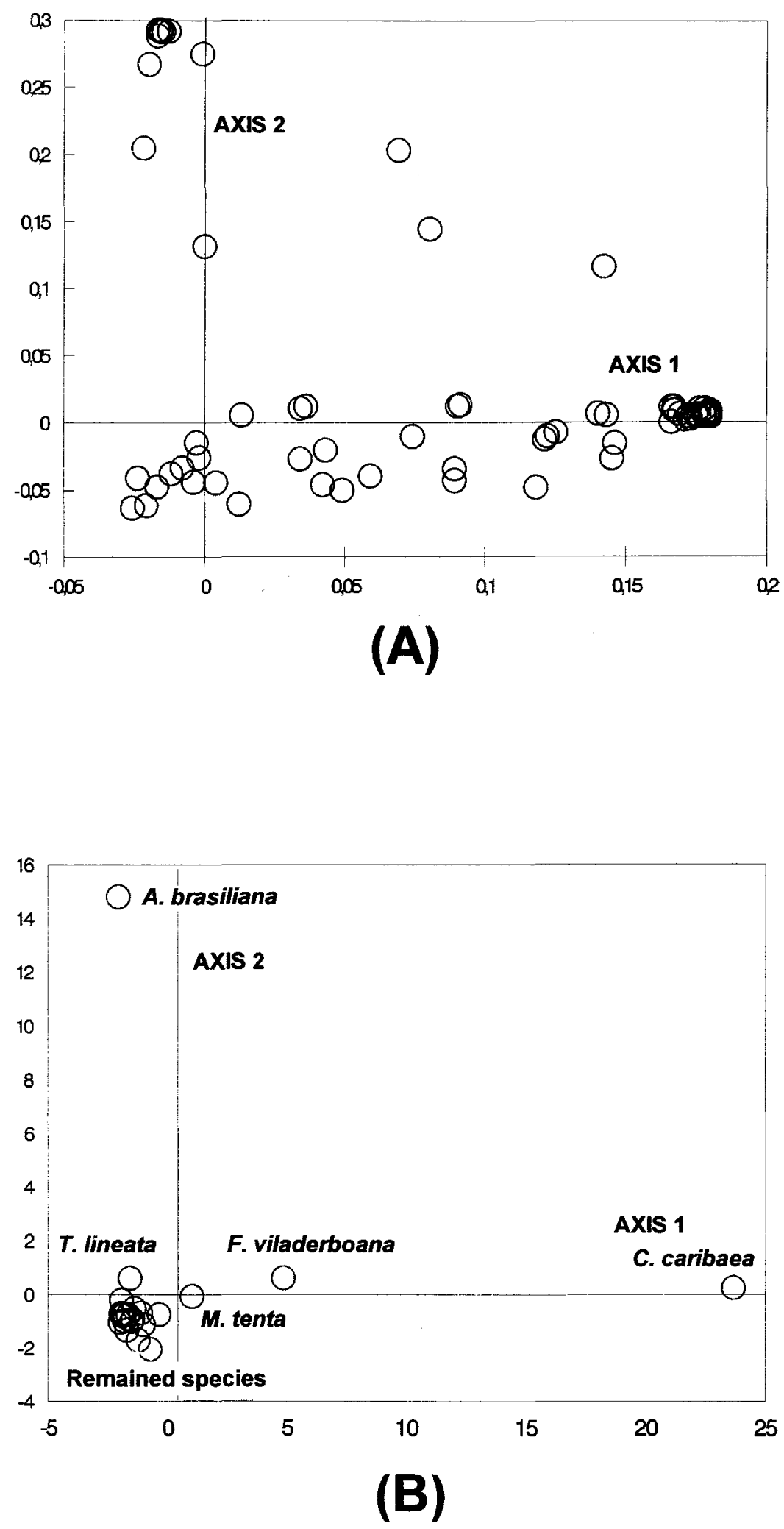

Fig. 5. Projection of stations (A) and species (B) against the first and second axes of variability from the P.C.A. 
The present study suggests that the spatial distribution of $A$. brasiliana was limited by physical factors, mainly by the silt-clay fractions. Corbula caribaea was less influenced by these factors in that it was the most frequent species in most of the types of sediment. The spatial distribution of C. caribaea appeared to be mostly influenced by the occurrence of $A$. brasiliana. However, the relative roles of physical and biological factors in the distribution of both species need to be determined by further research.

Granulometry and organic matter were the preponderant factors in determining abundance and spatial distributions of bivalves in the Saco do Céu Inlet. The majority of species recorded in the winter occurred in the summer as well. However, there was a distinction between the two periods of the year in relation to abundance and specific composition among similar types of sediment. Two different communities (one dominated by $C$. caribaea and other by $A$. brasiliana), were distributed in the form of continua along sediment gradients.

\section{Acknowledgements}

We thank all the members of the Laboratory of Benthos (Universidade Federal do Rio de Janeiro) for their assistance in field and laboratory work. We also thank Dra Fernanda Reinert for critically reading the manuscript. This research was supported by Brazilian governmental institution (FAPERJ/CAPES).

\section{References}

Anderlini, V. C. \& Wear, R. G. 1992. The effect of sewage and natural seasonal disturbances on benthic macrofaunal communities in Fitzroy Bay, Wellington, New Zealand. Mar. Pollut. Bull., 24(1):21-26.

Bachelet, G.; De-Mountaudouin, X. \& Dauvin, J. C. 1996. The quantitative distribution of subtidal macrozoobenthic assemblages in Arcachon Bay in relation to environmental factors: a multivariate analysis. Estuar. coast. Shelf Sci., 42(3):371-391.
Dauer, D. M. 1993. Biological criteria, environmental health and estuarine macrobenthic community structure. Mar. Pollut. Bull., 26(5):249-257.

Diener, D. R.; Fuller, S. C.; Lissner, A.; Haydock, C. J.; Maurer, D.; Robertson, G. \& Gerlinger, T. 1995. Spatial and temporal patterns of the infaunal community near a major outfall in Southern California. Mar. Pollut. Bull., 30(12):861-878.

Domschke, L. M. 1978. Anatomia funcional de Corbula caribaea (Orbigny, 1842) (Mollusca: Bivalvia). Dissertação de mestrado. Universidade de São Paulo, Instituto de Biociências. $54 \mathrm{p}$.

Folk, R. L. \& Ward, W. C. 1957. Brazos River Bay, a study in significance of grain-size parameters. J. sedim. Petrology, 27:2-26.

Franz, D. 1976. Benthic molluscan assemblages in relation to sediment gradients in Northeastern Long Island Sound, Connecticut. Malacologia, 15(2):377-399.

Fresi, E.; Gambi, M. C.; Focardi, S.; Bargagli, R.; Baldi, F. \& Falciai, F. 1983. Benthic community and sediment types: A structural analysis. Mar. Ecol., 4(2):101-121.

Gonçalves, E. M. \& Lana, P. C. 1991. Padrões de distribuição de bivalvia e gastropoda na plataforma continental da costa sudeste do Brasil (24 $\left.4^{\circ} \mathrm{S}-27^{\circ} \mathrm{S}\right)$. Nerítica, Pontal do Sul, (1-2):73-92.

Gray, J. S. 1981. The ecology of marine sediments. Cambridge, Cambridge University Press. 185p.

Horn, H. 1966. Measurement of overlap in comparative ecological studies. Am. Naturalist, 100:419-424. 
IEF. Instituto de Engenharia Florestal. 1992. Plano Diretor do Parque Estadual da Ilha Grande. UFRRJ/IEF-RJ/PRÓ-NATURA. 247p.

Ingram, R. L. 1971. Sieve analyses. Chapter 3. In: Carver, R. E. ed. Procedures in sedimentary petrology. $1^{\text {st }}$ ed. New York, WileyInterscience. p. 49-67.

James, R. J.; Lincoln Smith, M. P. \& Fairweather, P. G. 1995. Sieve-mesh size and taxonomic resolution needed to describe natural spatial variation of marine macrofauna. Mar. Ecol. Prog. Ser., 118:187-198.

Jones, G. P.; Ferrell, D. J. \& Sale, P. F. 1990. Spatial pattern in the abundance and structure of mollusc populations in the soft sediments of a coral reef lagoon. Mar. Ecol. Prog. Ser., 62(1-2):109-120.

Kamermans, P.; Veer, H. W. \& Karczmarski, L. 1992. Competition in deposit and suspensionfeeding bivalves: experiments in controlled outdoor environments. J. expl mar. Biol. Ecol., 162(1):113-135.

Lana, P. C.; Almeida, M. V. O.; Freitas, C. A. F.; Couto, E. G. C.; Conti, L. M. P.; Gonzalez-Peronti, A. L.; Giles, A. G.; Lopes, M. J. S.; Silva, M. H. C. \& Pedroso, L. A. 1989. Estrutura espacial de associações macrobênticas sublitorais de Gamboa Perequê (Pontal do Sul, PR). Nerítica, Pontal do Sul, 4(1-2):119-136.

Levinton, J. S. 1972. Stability and trophic structure in deposit-feeding and suspension-feeding communities. Am. Naturalist, 106:472-486.

Ludwig, J. A. \& Reynolds, J. F. 1988. Statistical Ecology. New York, Wiley-Interscience. $337 \mathrm{p}$.

Mills, E. L. 1969. The community concept in marine zoology, with comments on continua and instability in some marine communities: a review. J. Fish. Res. Bd. Can., 26:1415-1428.
Morrisey, D. J.; Howitt, L.; Underwood, A. J. \& Stark, J. S. 1992. Spatial variation in soft sediments benthos. Mar. Ecol. Prog. Ser., 81(2):197-204.

Neme, L. M. 1979. Distribuição e agrupamentos de bivalves na Baía de Ilha Grande, Rio de Janeiro (Mollusca). Tese de doutorado. Universidade de São Paulo, Instituto de Biociências. 71p.

Nybakken, J. W. 1988. Marine biology: an ecological approach. $2^{\text {nd }}$ ed. New York, Harper Collins Publishers. 514p.

Palacin, C.; Martin, D. \& Gili, J. M. 1991. Features of spatial distribution of benthic infauna in a Mediterranean shallow-water bay. Mar. Biol., 110(2):315-321.

Petrobrás. Petróleo Brasileiro S/A. 1991. Estudo dos efeitos da retenção de hidrocarbonetos em ambientes costeiros na Baía de Ilha Grande, RJ. Technical Report. 120p.

Pielou, E. C. 1969. An introduction to mathematical ecology. New York, WileyInterscience. $263 \mathrm{p}$.

Rhoads, D. C. \& Young, D. K. 1970. The influence of the deposit feeding organism on sediment stability and community trophic structure. J. mar. Res., 28:150-178.

Sanders, H. L. 1958. Benthic studies in Buzzards Bay. I. Animal-sediment relationship. Limnol. Oceanogr., 3(3):245-258.

Schaeffer-Novelli, Y. 1980. Análise populacional de A. brasiliana (Gmciin, 1791), na praia do Saco da Ribeira, Ubatuba, Estado de São Paulo. Bolm Inst. oceanogr., S Paulo, 29(2):351-355.

Siegel, S. 1975. Estatística não-paramétrica. $2^{\mathrm{a}}$ ed. São Paulo, McGraw-Hill. 333p. 
Soetaert, K.; Vincx, M.; Wittoeck, J.; Tulkens, M. \& Gansbeke, D. V. 1994. Spatial patterns of Westerschelde meiobenthos. Estuar. coast Shelf Sci., 39(4):367-388.

Suguio, K. 1973. Introdução à sedimentologia. São Paulo, Blücher/EDUSP. 317p.

(Manuscript received 22 August 1997; revised 09 December 1997; accepted 23 March 1998) 